\title{
Does Financial Inclusion Promote Women Empowerment? Evidence from Bangladesh
}

\author{
Md. Nur Alam Siddik \\ Correspondence: Md. Nur Alam Siddik, Assistant Professor, Department of Finance and Banking, Begum Rokeya \\ University, Rangpur-5400, Bangladesh.
}

Received: June 1, 2017

doi:10.11114/aef.v4i4.2514
Accepted: June 28, $2017 \quad$ Available online: June 28, 2017

URL: https://doi.org/10.11114/aef.v4i4.2514

\begin{abstract}
Financial inclusion empowers individuals and families, especially women and the poor, and well-functioning financial systems enrich whole countries. While a plethora of literature exists in connection between the financial inclusion and women empowerment most of those are cross country studies and findings are mixed. And there is relative dearth of studies examining the nexus of financial inclusion and women empowerment of developing economy, particularly Bangladesh. This study attempted to fill this gap. In order to achieve the objective, a survey, by means of structured questionnaire, has been conducted on 500 rural women living in the Kurigram and Gaibandha district of Bangladesh during January to February 2017. Study reveals that financial inclusion increases women income, purchasing power, living standard and position in the family. Study also reveals that after availing financial inclusion progrmmes, rural women become able to meet their emergencies, give child better education, get better medical facility, reduce dependency on local money lenders which means that financial inclusion programmes promotes women's economic empowerment. Findings of the study is of greater importance to the academicians, practitioners and policy makers of the country to design such packages as to foster financial inclusion which will lead to more women empowerment which in turn will lead to the inclusive development of the country.
\end{abstract}

Keywords: financial Inclusion, women empowerment, inclusive growth, microfinance, Bangladesh

\section{Introducation}

\subsection{Background}

Concept of "Financial inclusion" has developed as a tool to achieve inclusive growth since 2005, a year that the UN has announced International Microcredit Year. Financial inclusion empowers individuals and families, especially women and the poor to be included in the formal financial system and well-functioning financial systems enrich whole countries. The general consensus is that financial inclusion may contribute to achieve economic growth and poverty reduction goals of any country. It will enable millions of low-income people to improve their economic and social status by participating in the formal financial system. The economic policy of every nation has underscored the significance of an inclusive financial system. The advantages of an inclusive financial system can hardly be exaggerated. The foremost is that it expedites efficient distribution of productive resources by bringing marginalised sections in to the mainstream of economic development process. Further, access to appropriate financial services can significantly improve the financial discipline in the society and efficient management of finance. An inclusive financial system can also contribute in reducing financial distress which is widespread among people working in the informal sector by reducing lending practices adopted by local money lenders. Therefore, an inclusive financial system can definitely contribute for greater levels of efficiency and welfare by providing financial security and promote saving habits among masses. Due to higher costs and other constraints such as collateral, the poor and disadvantaged group, especially rural women cannot afford the financial services provided by formal financial services and thus are left out from the financial system which has a detrimental effect on the economic growth of a country. To get those excluded people involved in the development process of a country, policy makers around the world focused on financial inclusion policies.

Women empowerment is one of the recent priority issues in developing countries, since women have less salaried jobs. According to Mayoux (1998) empowerment is a multidimensional and intertwined method of change in relating to power. Krishna (2003) stated that women's empowerment is a process through which women can make their choices and renovate these choices into desired actions and outcomes. Economically empowering women is indispensable both 
to apprehend women's rights and to achieve broader development goals such as economic growth, poverty reduction, and social welfare. According to Golla, Malhotra, Nanda, \& Mehra (2011), when women have the ability to succeed and advance economically as well as have the power to make economic decisions, women are said to be economically empowered. While it is evident by researchers and scholars that women's economic empowerment promotes inclusive growth of a country, in many developing countries, still, female headed households are the poorest among the poor households. Evidence shows that a large portion of the hard-core poor are the women, because they face social barriers in accessing economic assets such as property and credits that make it is much harder for them to overcome poverty and they are more susceptible to becoming poor when they lose the male earning member of the family due to abandonment, divorce or death. Continued disparities between women and men in employment and income opportunities, education, and control over assets demonstrate that development activities are centered on the men.

\subsection{Research Problem}

Bangladesh is a predominantly rural based and agrarian country, where women constitute half of the population, majority of them are marginalized and live in utmost poverty. All modern financial institutions having credit operations of various types are mostly located in urban areas, and thus rural areas in general and particularly rural women are excluded from the financial intermediation. The patriarchal society of ours has put a check on women's potential, capabilities as well as self-confidence just because of their economic dependence on men folk. The unsung heroine, who works from dawn to dusk remains trapped in vicious circle of drudgery \& anonymity throughout the life presents a glaring example of gender-bias prevalent in our society. As woman's practical needs are closely linked to their socially defined gender roles, responsibilities, and social structures, to ensure equitable participation of women in the inclusive development process of the country the government has taken a number of steps to address the issue of women empowerment through financial inclusion to bring socio-economic change in the society.

The hypothesis that financial inclusion reduces poverty and empowers women has been a contentious issue in the academic and the public domain. The validity of the claim that financial inclusion empowers women has been questioned (Schicks, 2010; Goetz \& Gupta, 1996). The protagonists who are supporting the assumption that loans from micro-finance institutions empower women are (Hunt \& Kasynathan, 2002; Holvoet, 2005; Mahjabeen, 2008; Pitt, Khandker, \& Cartwright, 2006; Weiss \& Montgomery, 2005; Nisser \& Ayedh, 2017). The contentious debates on the validity of financial inclusion impacting women prompted this paper to investigate the role of financial inclusion in empowering women in Bangladesh. Therefore this study will investigate first of all, nexus between financial inclusion and women's economic empowerment which ultimately have impact on the inclusive growth of the country.

\subsection{Rationale of the Study}

Researchers, practitioners and academicians across the world contend that women's empowerment promotes inclusive growth of a country. Arguing the same, this research intends to focus on empowering women through financial inclusion which ultimately will have a positive impact on the development of the country. There is both an instrumental and an intrinsic rationale for such an explicit focus on women empowerment as recent research evidences on financial inclusion and women empowerment nexus are mixed. These mixed evidences may be due to geographic or demographic differences of the countries studied. The other thing is that most of the related studies focused only on microcredit and its impact on women which is a narrower concept. Financial inclusion is more than microcredit. Put simply, financial inclusion is microcredit plus. This calls for extensive studies which focus on investigating and establishing the nexus between financial inclusion and women's economic empowerment of a single country. Once the nexus is established, the government and policymakers could undertake such financial inclusion policies to promote women empowerment for the sake of acceleration of the inclusive development of the country. Therefore, using econometric methodology this study aims to inspect and establish a connection between financial inclusion and women's empowerment in the context of Bangladesh where almost half of the population is women. Findings of the study will help the policymakers of Bangladesh to undertake such financial inclusion programs to ensure greater participation of women in the country's development process.

\section{Literature Review}

\subsection{Conceptualizing Financial Inclusion}

Financial inclusio is multi-dimensional in approach. The basic issue is that the unbanked people when they approach formal financial institutions; they are confronted with problems of "accessibility, timeliness, and inadequacy of credit". For these reasons people are forced to approach the "informal agencies to meet their credit demands". It requires a revolutionary change to address these problems that are complex and are deep rooted. Karmakar (1999) stated that financial inclusion expedites credit to people of all segments of a country including vulnerable sections at an affordable cost, in a timely manner and in adequate amount. This definition put emphasis on that adequate amount of credit should be delivered to all types of demander of funds as they demand. There is no universal recognized meaning or indicator to 
measure financial inclusion. Nonetheless, it is commonly agreed that women's financial inclusion occurs when women have effective access to a wide range of financial products and services that satisfy their several business and household needs. Financial inclusion ensures the accessibility and availability of formal banking services to marginalized sections of the society. The basic level of financial inclusion means opening savings or current Account with any branch of a banking company. In a broad sense financial inclusion includes loans, deposit services insurance services, and much more.

\subsection{Conceptualizing Women Empowerment}

The term 'women empowerment' used in this research refer to economic empowerment of disadvantaged women who had no income and assets, and thus no control over family wealth. The OECD-DAC Network on Gender Equality defined women's economic empowerment as women's ability to take part in, contribute to, and equal advantages from process of inclusive growth through which their dignity, respect and equal opportunities are protected (OECD, 2011). Recently, in developing economies, a number of governments and non-government organizations (NGOs) have launched credit facilitating programs focused on the need of poor. Considering the fact that women are less likely to get credit, less access and low wage from the labor market, and inequitable power in making household' decision those credit programs have special focused on bringing these women into the formal financial system so that they can have easier credit facilities along with equal opportunities in the economy. This could be termed as women's financial inclusion.

Women's financial inclusion can increase women's empowerment in a number of ways. Firstly, through included in formal financial system women will have additional assets on their account which will intensify bargaining power of them within their households and also will have more ability to manage their daily financial matters. Secondly, at outside of household, once women are included in financial inclusion programs, they will become more able to control their assets. Thirdly, financial inclusion could, by means of insurance, assist them to diversify risk and thus reduce women's vulnerability. These are all key factors for economic empowerment and they can also help to empower women more broadly.

Financial inclusion seems to be a viable option for the rural women having no access to income and wealth. Therefore this research project attempts to investigate whether financial inclusion promotes women's income generation, enhances family assets, provides greater control over family wealth and thereby eventually economically empowers them, and also will try to justify users' satisfaction and suggest appropriate policy option addressing financial inclusion for women empowerment.

\subsection{Financial Inclusion and Women Empowerment Nexus: Empirical Evidence}

Financial inclusion is intended to connect people to banks with consequential benefits. Access to financial system facilitates creating equal opportunities, enables economically and socially excluded people to integrate better into the economy and protect themselves against economic shocks. The government of a state was seen as general agent of development and state intervention in the area of policy and prescriptions for enabling faster economic development and consequent inclusive growth (Epstein \& Grabel, 2006). The thoughts of development economics were once regarded as revolutionary and important and commanded intellectual patronage (Krugman \& Venables, 1995). In developing countries, economic paradigm is surely the most important and perhaps the most complex of all economic issues. The ideology of financial inclusion in developing economies is different from that of developed economies. In developed economies the target group may be a microscopic minority, in the developing economies it could be a majority. Therefore, the subject of financial inclusion in developing economies assumes greater significance. Financial inclusion will happen on its own. Holvoet (2005) compared the gender effects of two subsidized credit programs in southern India and found that the decision-making influence of women increases only when credit transfers are made to women. Similar studies by Pitt et al., (2006) revealed that there is positive correlation between FI programmes targeting women and their well-being. The findings of these studies reinforce the fact that women could be "active agents of change" and play an important role in both the family and the society. But the development policies have bypassed women leaving them in a position where they were since generations. Microfinance in the recent past has emerged as a potential instrument for poverty alleviation and women empowerment. Majority studies have established that an increase in women's resources results in increased wellbeing of the family as a whole (Hashemi, Schuler, \& Riley, 1996; Hulme \& Mosley, 1996; Kabeer, 2012; Mayoux, 1998). Microfinance and Micro insurance programmes have the potential to transform communities by alleviating poverty and empowering women.

In the context of Bangladesh, using panel data, Islam, Nguyen, \& Smyth (2015) observed that rural households' access to microfinance reduces their incidence of borrowing from informal source. Berger (1995) found that after availing microfinance services women become able to make decisions about credit and savings through they can manage their income-consumption behavior in a better way. Author also observed that this economic empowerment in turn lead to increased well-being of women. Islam, Ali, Salehin, \& Islam, (2008). investigated the impact of poverty focused Non-government organizations (NGOs) programs on rural women. Authors observed a wider disparity in employment and income, literacy and education, nutritional intake, and access to health facilities which is obvious obstacle to 
inclusive growth of a country. Mazumder and Wencong (2013) explored positive association between women's access to credit and socio-economic variables such as neighbors' respect, self-esteem, self-confidence, self-expression, ability to protest social injustice, capacity to solve social issues are applied to measure changes in social conditions of poor women. Malik and Luqman (2005) observed that microfinance raised women's economic status by assisting them to enhance their income through which they can experience more financial sovereignty. Authors observed that micro credit enabled poor women to engage in numerous income generating activities. Looking at several dimensions of women empowerment, Schurmann and Johnston (2009) study supports the positive linkage between microfinance and social performance, exemplified by microfinance's resilient positive effect on women's empowerment and a less verifiable impact on sexual and reproductive health. Hossain, Bose, \& Ahmad, (2004) investigated the role of microfinance institutions in supporting rural livelihoods in Bangladesh. Author observed that microfinance is making significant involvement in uplifting the rural people's livelihoods. Mayoux and Hartl (2009) observed that microfinance has contributed not only to goals of poverty reduction and financial sustainability, but also to economic empowerment, increased well-being and social and political empowerment for women themselves, thereby addressing goals of gender equality and empowerment. Narayan-Parker (2002) has strongly emphasized women empowerment as the processes by which women take control and ownership of their lives through expansion of their choices. Therefore, empowerment of women is an important goal of any development policy of an economy.

However, some research observed that financial inclusion programs did not aid in economic upliftment of the poor women (Navajas, Schreiner, Meyer, Gonzalez-Vega, \& Rodriguez-Meza 2000; Mosley 2001; Montgomery \& Weiss 2011). Swamy (2014) carried out a detailed study of Financial Inclusion, Gender and Economic Impact analysis. This study concludes that women in different regions of India are still not included in the formal financial system and thus have little impact on the growth of the country.

Evaluations of the effects of FI programs on women's empowerment generated mixed results. While some are supportive of FI programs' ability to induce a process of economic, social and political empowerment, others are more sceptical and even point to a deterioration of women's overall well-being. The significant of contribution of this study to the literature, the researcher claims, can be appreciated from backdrop that though there is a fairly high degree of disagreement on the impact of FI programs on

It is stated that 'when poor participate as subjects and not as objects of the development process, it is possible to generate growth, human development and equity, individually the poor women would not be able to overcome obstacles in their struggle for survival, security and self-respect, which they could do through collectives action'. The support mechanisms like government and nongovernment organizations provide the poor women a partnership. The poor collectively can start income generation activities with their own resources to achieve self-reliance with the support of this organization. Thus, starting from the socioeconomic base the poor women show increasing awareness, cooperation, self-reliance, self-management and move towards social consciousness, empowerment and self-respect. Many studies have demonstrated the impacts of financial inclusion scheme.

\section{Research Methodology}

\subsection{Sample, Data Collection and Description}

In order to investigate whether financial inclusion promote women empowerment, primary data have been collected from rural women living in Gaibandha and Kurigram district located in northern region of Bangladesh during January to February, 2017. We select these two districts as because financial inclusion of these two districts are low as evident by Siddik, Sun, \& Kabiraj (2015); also these are rural area and standard of living of women in this area are not better as compared to other areas. Simple random sampling method was used. In order to identify problems with instrument wording, format, content, usefulness and relevance the questionnaire was tested extensively for validity before the actual survey was administered. The survey was pilot tested with 20 respondents. On the basis of comments and results found in the pilot test, the survey was redesigned with some minor changes. The final paper-based questionnaires were then distributed to a total of 650 rural women. Out of the 650 rural women, 500 usable respondents were obtained (76.92\% response rate). 
Table 1. Profile of the respondents

\begin{tabular}{lll}
\hline $\begin{array}{l}\text { Demographics } \\
\text { Age (in years): }\end{array}$ & Frequency & Percentage \\
\hline Less than 20 years & 24 & 4.8 \\
20-29 years & 189 & 37.8 \\
30-39 years & 154 & 30.8 \\
40-49 years & 94 & 18.8 \\
50-59 years & 26 & 5.2 \\
60 years more & 13 & 2.6 \\
Education: & & \\
No formal education & 177 & 35.4 \\
Primary school & 143 & 28.6 \\
Higher secondary school & 114 & 22.8 \\
College & 30 & 6 \\
Bachelor degree & 12 & 2.4 \\
Master degree & 4 & 0.8 \\
Other & 20 & 4 \\
Income: & & \\
None & - & - \\
Less than 7000 BDT & 237 & 47.4 \\
7000-14999 BDT & 174 & 34.8 \\
15000-24999 BDT & 65 & 13 \\
25000-34999 BDT & 15 & 3 \\
35000-44999 BDT & 9 & 1.8 \\
\hline
\end{tabular}

\section{Empirical Results and Discussion}

\subsection{Survey Findings}

Following tables demonstrates the respondents' opinion about different indicators of women empowerment. As can be seen from the Table 2, 82.2\% rural women think that after availing financial inclusion programmes, they are more able to meet the emergencies arises whereas only $4.4 \%$ opined that they are not able to meet emergencies even after availing financial inclusion programmes.

Table 2. Able to meet emergencies

\begin{tabular}{lll}
\hline Respondent's Opinion & No. of respondents & Percentage \\
\hline Yes & 411 & 82.2 \\
No & 22 & 4.4 \\
No effect & 67 & 13.4 \\
\hline
\end{tabular}

According to findings provided in Table 3, we can argue that financial inclusion programmes have increased the purchasing power of rural women since $90.6 \%$ rural women opined the same. Nonetheless, $6 \%$ rural women think that financial inclusion programs have made no effect on their purchasing power.

Table 3. Increased your purchasing power

\begin{tabular}{lll}
\hline Respondent's Opinion & No. of respondents & Percentage \\
\hline Yes & 453 & 90.6 \\
No & 17 & 3.4 \\
No effect & 30 & 6.0 \\
\hline
\end{tabular}

Table 4 reveals that financial inclusion programmes reduced the need of borrowing money or goods from other as $79 \%$ 
rural women opined that after availing financial inclusion programmes they do not go for borrowing.

Table 4. Reduce need to borrow money or goods

\begin{tabular}{lll}
\hline Respondent's Opinion & No. of respondents & Percentage \\
\hline Yes & 395 & 79 \\
No & 65 & 13 \\
No effect & 40 & 8 \\
\hline
\end{tabular}

According to Table 5, 78.8\% rural women do not depend on local money lenders who charge high interest rate which means that most of the respondents go for formal financial market which an essential condition for well-functioning financial system.

Table 5. Reduce the dependency on local money lenders

\begin{tabular}{lll}
\hline Respondent's Opinion & No. of respondents & Percentage \\
\hline Yes & 394 & 78.8 \\
No & 75 & 15 \\
No effect & 31 & 6.2 \\
\hline
\end{tabular}

Findings of Table 6 indicates that after availing financial inclusion programmes, majority of the respondents( $83.8 \%)$ are able to get their children better education and $11.4 \%$ opined that their child are not getting better education even after availing financial inclusion programmes. This might because of rural infrastructure constraints of the country.

Table 6. Children get better education

\begin{tabular}{lll}
\hline Respondent's Opinion & No. of respondents & Percentage \\
\hline Yes & 419 & 83.8 \\
No & 57 & 11.4 \\
No effect & 24 & 4.8
\end{tabular}

Empirical results of Table 7 reveals that after availing financial inclusion programmes, $75 \%$ rural women are able to get better medical facility and $8.4 \%$ rural pined that financial inclusion programmes have no effect on getting better medication.

Table 7. Better medical facility

\begin{tabular}{lll}
\hline Respondent's Opinion & No. of respondents & Percentage \\
\hline Yes & 375 & 75 \\
No & 83 & 16.6 \\
No effect & 42 & 8.4
\end{tabular}

According findings of Table 8 , it is evident that financial inclusion programmes enhanced their source of income as because $80.8 \%$ rural women have now more source of income.However, $7.4 \%$ women think their source of income have not expanded.

Table 8. Increased source of income

\begin{tabular}{lll}
\hline Respondent's Opinion & No. of respondents & Percentage \\
\hline Yes & 404 & 80.8 \\
No & 37 & 7.4 \\
No effect & 59 & 11.8
\end{tabular}

Findings of Table 9 is of interesting and of significance. $74.2 \%$ rural women opined that their position in the family increased. In other words, Women have now better position in terms of decision making in the family. After included in financial inclusion programmes now they can decide which goods to consume, which products to produce etc. 
Table 9. Increased position in the family

\begin{tabular}{lll}
\hline Respondent's Opinion & No. of respondents & Percentage \\
\hline Yes & 371 & 74.2 \\
No & 65 & 2.6 \\
No effect & 64 & 13
\end{tabular}

According to Table 10, majority of the respondents (92.6\%) opined that their living standards have been improved. Now, they can consume more, produce more, getting better health and so on. It clearly indicates the success of financial inclusion programs and its productive benefits for the rural women. Financial inclusion significantly increased rural women's income and due to increased income they achieved better financial status. They could easily fulfill the requirements of household expenditures and needs of livelihood. Thus living standard and easier access to the several facilities of life of rural women have improved.

Table 10. Improved living standard

\begin{tabular}{lll}
\hline Respondent's Opinion & No. of respondents & Percentage \\
\hline Yes & 463 & 92.6 \\
No & 13 & 2.6 \\
No effect & 24 & 4.8 \\
\hline
\end{tabular}

\subsection{Test of Hypotheses}

We conducted Chi square test to examine the association between financial inclusion programmes and women empowerment where financial inclusion variables act as independent variables and women's economic empowerment variables, as mentioned above, are dependent variables. Findings are provided in Table 11. According to Table 11, there is significant association between the variables. As the level of significance of the computed value is less than $0.05(5 \%$ level of significance), so the alternative hypothesis that there is an association between financial inclusion and women's economic empowerment is accepted. Our findings are similar to the findings of Islam et al., (2015) and Schurmann and Johnston (2009). Thus we conclude that financial inclusion promotes women empowerment in developing economies, like Bangladesh.

Table 11. Results of Association between Financial inclusion and women empowerment

\begin{tabular}{lllc}
\hline & Value & Df & Asymp. Sig. (2-sided) \\
\hline Pearson Chi-Square & 32.23 & 5 & $.000 * * *$ \\
Likelihood Ratio & 24.67 & 5 & $.000 * * *$ \\
Linear-by-Linear Association & 15.92 & 1 & $.000 * * *$ \\
No. of Valid Cases & 500 & & \\
\hline
\end{tabular}

\section{Conclusions}

Women in northern region of Bangladesh belong to the ranks of unbanked and uninsured. They are experiencing high levels of financial distress as they are subjected to a wide range of financial and health risks. This study examined whether financial inclusion promotes women empowerment on the argument that if we can empower women, it will have a positive impact on the country's growth process. To examine the relationship, we conducted a survey in the two districts of northern region where most of women are poor and unbanked. We found that after availing financial inclusion programs, rural women become economically empowered and thus this study concludes that financial inclusion promotes women's economic empowerment. Our findings are similar to the findings of Islam et al., (2015) and Schurmann and Johnston (2009). Thus we conclude that financial inclusion promotes women empowerment. On the ground that bringing rural women into the mainstream financial system will have positive impact on their efficiency which is critical for inclusive growth, this study highlighted all these issues and calling for the policy revision to make the financial inclusion programmes more conducive and more convenient.

\subsection{Limitations and/or Scope for Future Research}

As in most empirical research, this study has several limitations which actually create scope for future researches.

Firstly, this study is conducted in Kurigram and Gaibandha district, Bangladesh, where most of the people live in rural areas. Moreover, the research surveyed about 500 respondents chosen randomly from Kurigram and Gaibandha district only. Secondly, the sample size of this study is 500 respondents only, and thus these findings may not be generalized to the whole issue based on this study alone. Therefore, in future research, it would be logical to elevate sample size and 
testing this model more extensively, hence this future research would be more generalizable. There exists a possible bias in the information provided by the respondent's majority who are illiterate. Analysis of perception about effectiveness of financial inclusion programmes is based on only few parameters. Lastly, as individuals gain experience over time, their perception and attitude changes. The conclusions drawn from this study are based on cross-sectional data, so it would be interesting to use a longitudinal study to assess the effects of financial inclusion programmes. A longitudinal study would provide greater insight into the causality and the interrelationships between variables and thus make comparisons with our model.

\section{References}

Berger, M. (1995). Key issues in women's access to and use of credit in the micro-and small-scale sector, IT Publications, London.

Epstein, G., \& Grabel, I. (2006). Financial policies for pro-poor growth, A study prepared for the United Nations Development Program (UNDP), International Poverty Centre, Global Training Programme on Economic Policies for Growth, Employment and Poverty Reduction.

Goetz, A. M., \& Gupta, R. S. (1996). Who takes the credit? Gender, power and control over loan use in rural credit programs in Bangladesh. World Development, 24, 45-63. https://doi.org/10.1016/0305-750X(95)00124-U

Golla, A. M., Malhotra, A., Nanda, P., \& Mehra, R. (2011). Understanding and measuring women's economic empowerment: Definition, framework, indicators, International Centre for Research on Women, Washington D.C.

Hashemi, S. M., Schuler, S. R., \& Riley, A. P. (1996). Rural credit programs and women's empowerment in Bangladesh. World development, 24, 635-653. https://doi.org/10.1016/0305-750X(95)00159-A

Holvoet, N. (2005). The impact of microfinance on decision - making agency: evidence from South India. Development and Change, 36, 75-102. https://doi.org/10.1111/j.0012-155X.2005.00403.x

Hossain, M., Bose, M. L., \& Ahmad, A. (2004). Nature and impact of women's participation in economic activities in rural Bangladesh: insights from household surveys. Occasional Paper, 41, International Rice Research Institute (IRRI), Manila, Philippines.

Hulme, D., \& Mosley, P. (1996). Finance against poverty: Effective institutions for lending to small farmers and microenterprises in developing countries. Routledge, London.

Hunt, J., \& Kasynathan, N. (2002). Reflections on microfinance and women's empowerment. Development Bulletin, 57, $71-75$.

Islam, A., Nguyen, C., \& Smyth, R. (2015). Does microfinance change informal lending in village economies? Evidence from Bangladesh. Journal of Banking \& Finance, 50, 141-156. https://doi.org/10.1016/j.jbankfin.2014.10.001

Islam, M. M., Ali, R. N., Salehin, M. M., \& Islam, A. H. M. S. (2008). Rural women and poverty: A study on the role of RDRS for poverty alleviation in Bangladesh. Journal of the Bangladesh Agricultural University, 6, 415-421.

Kabeer, N. (2012). Women's economic empowerment and inclusive growth: labour markets and enterprise development. SIG working paper 2012/1, International Development Research Centre.

Karmakar, K. G. (1999). Rural credit and self-help groups: micro-finance needs and concepts in India, Sage Publications India Pvt Ltd, New Delhi, India

Krishna, A. (2003). Social capital, community driven development and empowerment: a Short note on concepts and operations. World Bank working paper No. 33077, World Bank, Washington D.C. https://doi.org/10.1596/0-8213-5529-5

Krugman, P., \& Venables, A. J. (1995). Globalization and the Inequality of Nations. The quarterly journal of economics, 110, 857-880. https://doi.org/10.2307/2946642

Mahjabeen, R. (2008). Microfinancing in Bangladesh: Impact on households, consumption and welfare. Journal of Policy modeling, 30, 1083-1092. https://doi.org/10.1016/j.jpolmod.2007.12.007

Malik, N. H., \& Luqman, M. (2005). Impact of Microcredit on Women Empowerment: A review paper. Pakistan Journal of Agriculture Science, 42, 100-105.

Mayoux, L. (1998). Participatory Learning for Women's Empowerment in Micro-Finance Programmes: Negotiating Complexity, Conflict and Change. IDS bulletin, 29, 39-50. https://doi.org/10.1111/j.1759-5436.1998.mp29004005.x

Mayoux, L., \& Hartl, M. (2009). Gender and rural microfinance: Reaching and empowering women, International Fund 
for Agricultural Development (IFAD), Italy.

Mazumder, M. S. U., \& Wencong, L. (2013). Micro-credit and poverty reduction: a case of Bangladesh. Prague economic papers, 22, 403-417. https://doi.org/10.18267/j.pep.459

Montgomery, H., \& Weiss, J. (2011). Can commercially-oriented microfinance help meet the millennium development goals? Evidence from Pakistan. World Development, 39, 87-109. https://doi.org/10.1016/j.worlddev.2010.09.001

Mosley, P. (2001). Microfinance and poverty in Bolivia. Journal of Development Studies, 37, 101-132. http://dx.doi.org/10.1080/00220380412331322061

Narayan-Parker, D. (2002). Empowerment and poverty reduction: A sourcebook. World Bank Publications, Washington, D.C.

Navajas, S., Schreiner, M., Meyer, R. L., Gonzalez-Vega, C., \& Rodriguez-Meza, J. (2000). Microcredit and the Poorest of the Poor: Theory and Evidence from Bolivia. World development, 28, 333-346. https://doi.org/10.1016/S0305-750X(99)00121-7

Nisser, A. H. I., \& Ayedh, A. M. A. (2017). Microfinance and Women's Empowerment in Egypt. International Journal of Business and Economic Affairs, 2, 52-58.

OECD (2011). Women's economic empowerment. The Paris Declaration Monitoring Survey Frequently Asked Questions and Glossary, OECD-DAC GENDERNET, Paris.

Pitt, M. M., Khandker, S. R., \& Cartwright, J. (2006). Empowering women with micro finance: Evidence from Bangladesh. Economic Development and Cultural Change, 54), 791-831. https://doi.org/10.1086/503580

Schicks, J. (2010). Microfinance Over-Indebtedness: Understanding its drivers and challenging the common myths. CEB Working Paper No. 10, Solvay School of Business, Centre Emilee Bergheim, Bruxelles.

Schurmann, A. T., \& Johnston, H. B. (2009). The group-lending model and social closure: microcredit, exclusion, and health in Bangladesh. Journal of Health, Population and Nutrition, 27, 518-527. https://doi.org/10.3329/jhpn.v27i4.3398

Siddik, M. N. A., Sun, G., \& Kabiraj, S. (2015). Financial inclusion and its determinants: A study of Bangladesh. Indian Journal of Finance, 9, 7-29.

Swamy, V. (2014). Financial inclusion, gender dimension, and economic impact on poor households. World development, 56, 1-15. https://doi.org/10.1016/j.worlddev.2013.10.019

Weiss, J., \& Montgomery, H. (2005). Great expectations: microfinance and poverty reduction in Asia and Latin America. Oxford Development Studies, 33, 391-416. http://dx.doi.org/10.1080/13600810500199210

\section{Copyrights}

Copyright for this article is retained by the author(s), with first publication rights granted to the journal.

This is an open-access article distributed under the terms and conditions of the Creative Commons Attribution license which permits unrestricted use, distribution, and reproduction in any medium, provided the original work is properly cited. 